\title{
STUDY THE EFFECT OF FORWARD SPEED INFLATION PRESSURE OF REAR WHEELS AND SOIL MOISTURE ON THE TRACTOR FIELD PERFORMANCE
}

\author{
M. S. Himoud ${ }^{1}$; M. M. Mostafa ${ }^{2}$; E. A. El-Sahhar ${ }^{2}$; M. A. Elnono ${ }^{2}$
}

ABSTRACT

The effect of forward speed, inflation pressure of rear wheels and soil moisture on the tractor field performance has been investigated in this study during ploughing by using moldboard plough in order to evaluate the drawbar pull, tractor wheel slippage tractive efficiency, the required power, specific energy, effective field capacity, field efficiency, and fuel consumption. The experiments were carried out using four different forward speeds (1.8, 2.33, 3.88 and $4.68 \mathrm{~km} / \mathrm{h})$ of Massey Ferguson 285S, three inflation pressures of rear wheel $(50,100,150 \mathrm{kPa})$, the average soil moisture content Mcdb $(14.67 \%, 24.18 \%)$ dry basis, and the average of ploughing depth (from 10 to $20 \mathrm{~cm}$ ). The soil texture was found to be silty clay. The results for the range of tests, showed that the maximum attractive efficiency was obtained at $3.67 \mathrm{~km} / \mathrm{h}$ travelling speed, $14.67 \%\left(M_{c b d}\right), 100 \mathrm{kPa}$ inflation pressure of tractor rear wheels, while the drawbar pull, wheel slippage, effective field capacity, field efficiency, rate of fuel consumption, required power and specific energy were $10.60 \mathrm{kN} .5 .58 \%, 1.45 \mathrm{fed} / \mathrm{h}, 77 \%, 8 \mathrm{~L} / \mathrm{h}, 25.55 \mathrm{~kW}$ and $17.02 \mathrm{~kW} . \mathrm{h} / \mathrm{fed}$ respectively.

Key words: Tractor, inflation pressure, tractive efficiency, forward speeds

\section{INTRODUCTION}

$N$ owadays, energy consumption is one of the world interests. Implements consume large amount of energy used in agricultural mechanization systems. The field performance operation of tractor is limited by constructing and operation factors as power supplied from the engine to the drive wheels.

The fuel consumption considered one of the factors that is used to evaluate the performance of tractors in field. The knowing the fuel

\footnotetext{
${ }^{1}$ Graduate student, Agric. Eng. Dept, Faculty of Agric., Ain shams Univ.

${ }^{2}$ Agric. Eng. Dept., Faculty of Agric., Ain shams Univ.
} 
consumption in studying the technical effects and economic costs for mechanization unit, is the most important factor. The consideration of tractor fuel consumption in tillage operations using mouldboard at various depths and speeds were therefore examined in a bid to minimize operating costs and maximize farm profit margins. The fact that cost of fuel constitute over $70 \%$ of tractor operating costs Al-Suhaibani et al. (2009). In order to have a feasible operation, the power supplied by the engine must be enough to meet the pull requirement of the implement at given working condition which include the strength of the soil, depth of operation and working speed. Lyasko (2010) Indicated that the soil conditions significantly affect tractive performance of off-road wheeled and tracked vehicles. Gee-Clough (1980) found that, tire inflation pressure will of course have a strong effect on tire deflection as well as tire side stiffness, both of these factors are known to affect tractive performance. He also presented the relationships between power efficiency, wheel slip and specific fuel consumption. The results of this study may provide helpful indications for an appropriate choice of tractor configuration, as well as for the reasonable wheel control. Khan and Ari (1980) found that the slippage horsepower increases by increasing the drawbar pull and forward speed. Hunt (1983) indicated that the rolling resistance is the force required to keep the equipment moving at a constant speed and is proportional to equipment weight .The term coefficient of rolling resistance is the ratio of horizontal required force to pull a loaded wheel over a horizontal surface to the vertical force on the wheels axle . Jebur et. al. (2013) proved that the travelling speed and the weight on the rear tractor wheels were the most important factors that affecting the drawbar pull and the specific energy. Younis et. al. (2010) indicated that the maximum drawbar power $(62.31-62.58 \mathrm{~kW})$ affected by drawbar pulls at highest forward speed of $(6.7-6.72 \mathrm{~km} / \mathrm{hr})$, respectively. Khader (2008) mentioned that, as the forward speed increased, The drawbar pull, specific energy, actual field capacity and fuel consumption were increased. Abraham et.al.(2014) indicated that the higher increasing in drawbar pull was measured during the tractor operation on 
the soil with higher moisture in comparison the soil with lower moisture level. In case of soil moisture $14 \%$ the increase in drawbar pull of tractor equipped with special wheels reached the value $17.2 \%$ in compare with standard tires. Using the special wheels on the same field with higher level of soil moisture $22 \%$ the increase in drawbar pull reached the value $36.1 \%$ in compare with standard tires..Lyne et al. (1989) stated that, tractive efficiency can be optimized by selecting the appropriate dynamic load and inflation pressure. Jebur (2010) mentioned that, fuel consumption is a better indicator of energy requirement for each implement. Sümer and Sabanci (2004) found that the overall tractor efficiency was increased by $3.44 \%$, while specific fuel consumption was decreased by $3.08 \%$ on average with radial-ply tires compared to bias-ply tires. Abdel-Wahab (1994) noticed that the fuel consumption (1/fed) increased as the forward speed increased. He also showed that the increase in the forward speed resulted in an increase in slip, draft and consumed energy. Bukhari and et al. (1982) assured the influenced factors was one of factor in consumption fuel was moisture content for soil and also plough type. Sarhan et al. (2010) noted that increase speed of the tractor led to increase field capacity (from 0.406 to $1.07 \mathrm{fed} / \mathrm{h}$ ), fuel consumption (from 6.25 to $9.94 \mathrm{~L} / \mathrm{h}$ ) and operation costs (from 18.1 to 20.642 L.E/h). Meanwhile, the field efficiency ( $\eta f)$ decreased about (from 70.81 to $64.23 \%$ ) and costs operation (L.E./fed) about (43.39 to 18.85 L.E./fed). Bahnas et al. (2004) studied the effect of machine forward speed on the field capacity, they showed that increase of tractor speed( from 2.5 to $5.5 \mathrm{~km} / \mathrm{h}$ ) leds to increase the actual field capacity ( form 0.8 to $1.6 \mathrm{fed} / \mathrm{h}$ ). This phenomenon could be illustrated that any machine utilized lower operating time as the forward speed increased. Al.Ani and et al. (1995) showed that the increasing of ploughing depth leds to lowering of practical speed and productivity, while the increasing of practical speed, increased the productivity, process. Tomkins and Wilhelm (1982) mentioned that for tillage and planting implements operated at various ground speeds, the energy input per unit area tended to increases for implements as the speed of operation was increased. 
Consequently, the present work is mainly concerned with testing, the field tractor performance including tillage operation at different forward speed, inflation pressure of rear wheels, and soil moisture content .It also determines and discusses the following objective.

1- Slippage, rolling resistance, power requirement and specific energy.

2- Effective field capacity and field efficiency.

3- The fuel consumption and economic evaluation in order to get the optimum tractor field performance.

\section{MATERIALS AND METHODS}

This work was carried out in Faculty of Agriculture Basrah University, Iraq, during summer 2013. Tractor performance was evaluated at (a) 1500 rpm engine speed; (b) four forward speeds $(1.8,2.23,3.88,4.68 \mathrm{~km} / \mathrm{h})$; (c) three inflation pressure of rear wheel $(150,100$ and $50 \mathrm{kPa})$; (d) two levels of soil moisture content $(14.67 \%, 24.18 \%$ dry basis) and (e) plowing depth (from 10 to $20 \mathrm{~cm}$ ) each experimental area was $(50 \times 1.22=$ $\left.61 \mathrm{~m}^{2} \approx 0.0145 \mathrm{Fed}\right)$. Three replicates were used for measurements at the selected forward speed, inflation pressure of rear wheels, soil moisture content, and plowing depth. Then, for each factor, the average tractive force, rolling resistance, and net drawbar pull was calculated .

The mechanical analysis of the soil is shown in table (1).

Table (1) Mechanical analysis of the experimental soil.

\begin{tabular}{|l|l|l|l|}
\hline \multicolumn{4}{|c|}{ Soil fraction } \\
\hline Clay, \% & Silt, \% & sand \% & Soil textural class \\
\hline 46.1 & 38.7 & 15.2 & Silt clay \\
\hline
\end{tabular}

The following materials and methods were used

\section{A-Materials.}

1.Tractor: Two tractors were used in this study ,namely, Massey Ferguson 285s and John deere , which have the following specifieation:

\section{a - Massey Ferguson 285S.}

Engine HP at R.P.M

Forward Speed

Engine type

Fuel type and No. of cylinders

Bore and stroke $(\mathrm{mm})$
77 at 2200

$\mathrm{G} 1=2.34, \mathrm{G} 2=3.24, \mathrm{G} 3=7.05 \mathrm{G} 4=7.38 \mathrm{Km} / \mathrm{h}$

perkins

Diesel, 4 cylinders

$100.96 \times 127$ 
Tire size front, rear 7.50-16, 18.4/15-30

proportion pressure

Cooling system

Weight $(\mathrm{kg})$

\section{b . John Deere}

Engine HP at R.P.M

Fuel type and No of cylinders

Bore and stroke (mm)

Tire size front, rear

proportion pressure

Cooling system

Weight (kg)

\author{
16:1 \\ Water \\ $16: 1$ \\ 3000
}

75 at 2200

Diesel,4 cylinders

$102 \times 129$

$7.50-16,18.4 / 15-30$

$16: 1$

Water

3100

\section{2 . Moldboard plow}

the specifications of the moldboard plough were :

$\begin{array}{ll}\text { Type } & \text { Deep digger } \\ \text { number of bottom } & 3 \\ \text { Working Width }(\mathrm{m}) & 1.22 \\ \text { Weight }(\mathrm{kg}) & 300\end{array}$

\section{Load cell}

A load cell (cylindrical S. Beam.Type, L.SB600 Model, and 111.2 kN Capacities) is considered as an imitative and empirical technique for measuring the tractive force in this study .The load cell system is illustrated in Fig.(1). It consists of:

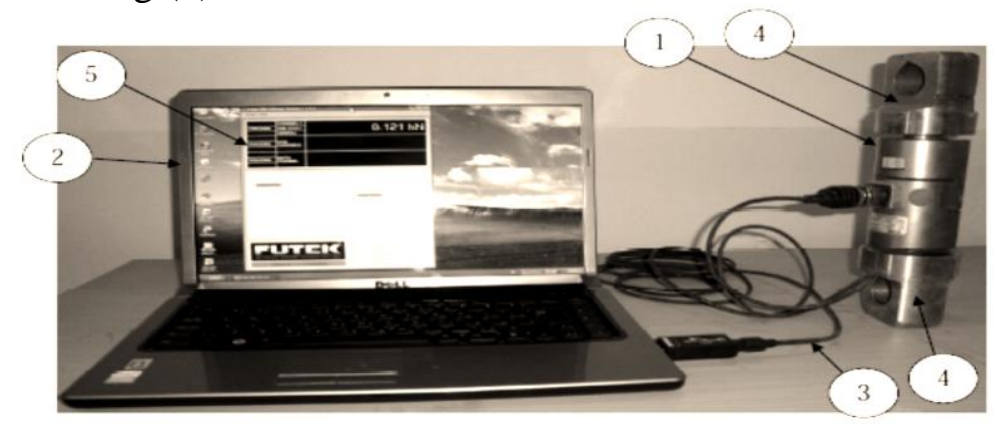

Fig (1) load cell system

1. Load cell

2. Computer

3. Data wire

4. Points for fixing system in tractor source and load source

5. Program for recording and save data on computer. 


\section{Measuring instruments:}

1- Spring dynamometer

2- Stop watch.

3- $50 \mathrm{~m}$ tape.

4- Fuel consumption apparatus by volume as recommended by Jebur (2013)

\section{B- Methods :}

\section{1- Soil moisture content $\left(\mathbf{M}_{\text {cbd }}\right)$}

Soil moisture content was determined by using the standard oven methods. Soil samples were taken at depths (from 0 to $20 \mathrm{~cm}$ ) by screw ouger. They were weighted, and then dried at $105{ }^{\circ} \mathrm{C}$ for $24 \mathrm{~h}$ in electric oven. The moisture content was calculated according to (Black et. al. 1965) as:

Where

$$
M_{c b d}=\left(\frac{W_{W}-W_{d}}{W_{d}}\right) \times 100
$$

$\mathrm{M}_{\mathrm{cbd}}=$ Soil moisture content (dry basis) $\%$

$\mathrm{W}_{\mathrm{w}}=$ wet soil mass, $\mathrm{gm}$

$\mathrm{W}_{\mathrm{d}}=$ dry soil mass, gm

\section{2- Travelling speed (TS)}

It was calculated as follows

Where

$$
T S=\frac{x}{t} \times 3.6
$$

$\mathrm{TS}=$ travelling speed,$(\mathrm{km} / \mathrm{h})$

$\mathrm{x}=$ travelling measured distance, $(\mathrm{m})$

$\mathrm{t}=$ travelling measured time, $(\mathrm{s})$

\section{3- Tractive force}

A horizontal steel wire with load cell linked the two tractor as in Fig (2) .The load cell was joined to a force transducer. A laptop computer was used to store data for analysis The rear tractor which carried the moldboard plough was being in neutral gear and the experiments were conducted by lowering the plough at the operating depth, then tractive 
force $(\mathrm{k} \mathrm{N})$ was recorded in measuring distance of $50 \mathrm{~m}$ as well as the time taken to traverse it. On the same field the plough was lifted out of the ground and the rear tractor was pulled to record the rolling resistance $(\mathrm{kN})$, then the net drawbar pull $(\mathrm{kN})$ was calculated as the followings: net drawbar pull, $\mathrm{kN}=$ Tractive force $(\mathrm{kN})$ - Rolling resistance $(\mathrm{kN})$

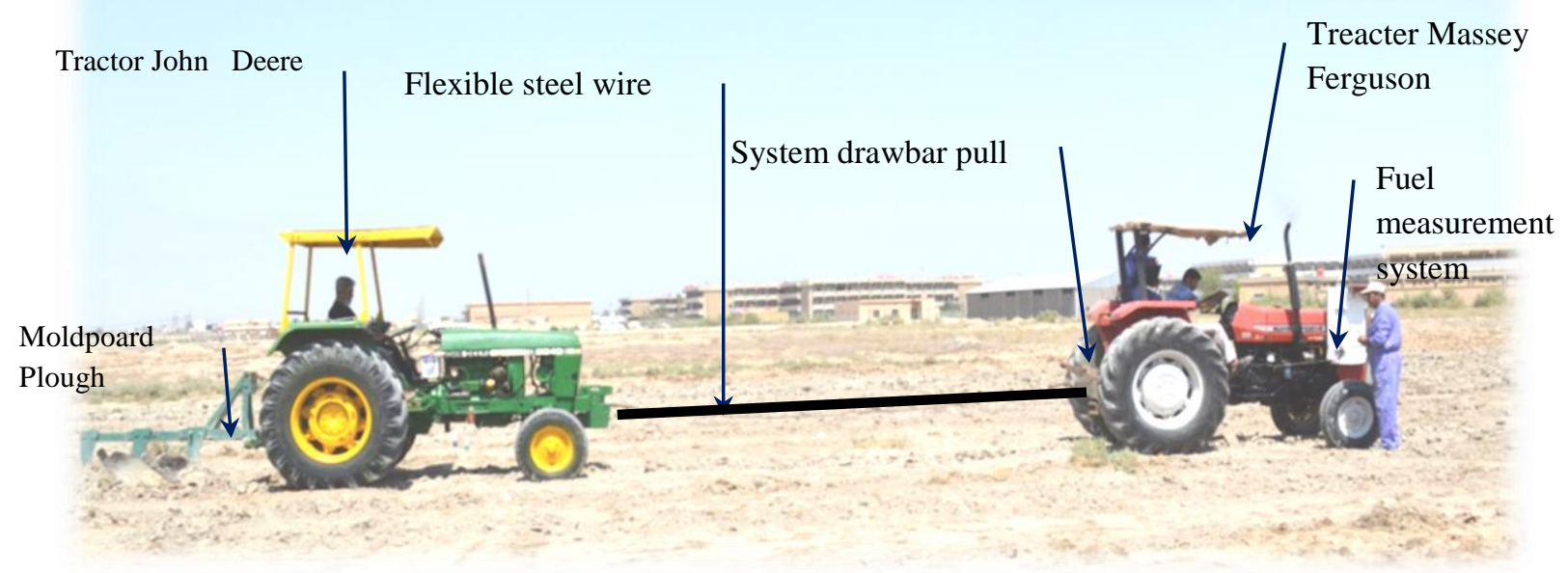

Fig. (2) Measuring the tractive force

\section{4-Rolling Resistance}

Rolling resistance for MF205S tractor was measured in the field at the same selected speed, inflation pressure of the rear wheels, and soil moisture content. The tested tractor was pulled using another. Then, the rolling resistance recorded directly in measuring distance of $50 \mathrm{~m}$ using the load cell basic components that were described at an early stage.

\section{5- Fuel consumption (FC)}

Fuel consumption per unit time was determined by measuring the volume of consumed fuel during ploughing time. It was calculated as follows:

$$
F C=\left(\frac{V}{t}\right) \times 3.6
$$

Where

FC : rate of fuel consumption, $1 / \mathrm{h}$

$\mathrm{V}$ : volume of consumed fuel, $\mathrm{cm}^{3}$

$\mathrm{t} \quad$ : time, $\mathrm{s}$ 


\section{6- Wheel slip (S):}

The slippage percentage was measured by using the following formula (Sharma and Mukesh 2010)

Where

$$
S=\frac{T S_{1}-T S_{2}}{T S_{1}} \times 100
$$

$\mathrm{S} \quad$ : wheel slip, \%

$\mathrm{TS}_{1} \quad$ : traveling speed without load $\mathrm{km} / \mathrm{h}$.

$\mathrm{TS}_{2} \quad$ : traveling speed with load $\mathrm{km} / \mathrm{h}$.

\section{6- Drawbar power $\left(\mathbf{P}_{\mathrm{db}}\right)$ :}

Drawbar Power $(\mathrm{kW})=$ Net drawbar pull $(\mathrm{kN}) \times$ traveling speed $(\mathrm{km} / \mathrm{h}) / 3.6$

\section{7- Drawbar specific fuel consumption:}

Drawbar specific fuel consumption (D.S.F.C) was calculated at the following:

Where:

$$
\text { D.S.F.C }=\frac{F . C(L / h)}{P(k W)}
$$

D.S.F.C : Drawbar specific fuel consumption (1/kW.h)

F.C : rate of volumetric fuel consumption, $(1 / \mathrm{h})$

$\mathrm{P} \quad$ : drawbar power $(\mathrm{kW})$.

8-Power consumed by rolling resistance $\left(P_{\mathrm{rr}}\right)$ :

Rolling resistance power $(\mathrm{kW})=$ rolling resistance $(\mathrm{kN}) \times$ traveling speed $(\mathrm{km} / \mathrm{h}) / 3.6$

\section{9- Tractive efficiency (TE):}

Tractive efficiency is defined as:

$$
T E=\frac{\text { Output Power }}{\text { Input power }} \times 100 \Rightarrow \frac{\text { Drawbar Power }}{\text { Axle power }} \times 100
$$

(Barger et. al. 1963, and Sharma and Mukesh 2010)

where $\mathrm{TE}=$ tractive efficiency $\%$ 


\section{0- Effective Field capacity $\left(\mathbf{E}_{\mathrm{fc}}\right)$}

Theoretical and effective field capacity was calculated according to the following formula:

Theoretical field capacity $=\frac{\text { Machine } \operatorname{width}(\mathrm{m}) \times \operatorname{speed}(\mathrm{km} / \mathrm{h})}{4.2} \ldots \mathrm{fed} . \mathrm{h}^{-1}$

Effective field capacity $=\frac{1}{\text { effective total time in hours required per feddan }} \ldots$ fed. $h^{-1}$

\section{1- Field efficiency $\left(\boldsymbol{\eta}_{\boldsymbol{f}}\right)$ :}

Field efficiency was calculated as the following:

$$
\eta_{f}=\left(\frac{E_{f . c}}{T_{f . c}}\right) \times 100
$$

Where:

$\eta_{\mathrm{f}} \quad$ : field efficiency, $\%$

$\mathrm{E}_{\mathrm{f.c}} \quad$ : effective field capacity, fed/h.

$\mathrm{T}_{\mathrm{f} . \mathrm{c}} \quad$ : theoretical field capacity, fed/h.

\section{1- Required engine Power (R.E.P):}

The required engine power was determined for each operation by using the following equation (Embaby, 1985).

$$
\text { R.E.P }=\left(F_{C} \times \frac{1}{3600}\right) \times \rho_{f} \times L . C . V \times 427 \times \eta_{t h} \times \eta_{m} \times \frac{1}{75} \times \frac{1}{1.36}
$$

Where:

R.E.P : Power Requirements from fuel consumption; $\mathrm{kW}$.

$\mathrm{F}_{\mathrm{c}} \quad$ : Fuel consumption rate; $\mathrm{L} / \mathrm{h}$

$\rho_{f} \quad$ :Density of the fuel; $\mathrm{kg} / \mathrm{L}$ (for diesel fuel $=0.85 \mathrm{~kg} / \mathrm{L}$ )

L.C.V : Lower calorific value of fuel $\mathrm{kcal} / \mathrm{Kg}$; (average L.C.V of diesel fuel is $10^{4} \mathrm{kcal} / \mathrm{kg}$ )

427 : Thermo - Mechanical equivalent; $\mathrm{kg} \mathrm{m} / \mathrm{kcal}$; 
$\eta_{\text {th }} \quad$ : Thermal efficiency of the engine (assumed to be $40 \%$ for diesel engine);

$\eta_{\mathrm{m}} \quad$ : Mechanical efficiency of the engine (assumed to be $80 \%$ for diesel engine).

\section{2- Specific Energy (SE):}

The specific energy ( $\mathrm{kW} . \mathrm{h} / \mathrm{fed})$ for a particular operation was calculated as follows:

$$
S E=\frac{R \cdot E . P}{E_{f . c}}
$$

Where:

SE : specific energy, kW.h/fed.

R.E.P : power required for a particular operation, $\mathrm{kW}$,

$\mathrm{E}_{\mathrm{f} . \mathrm{c}} \quad$ : effective field capacity, fed/h.

\section{RESULTS AND DISCUSSION}

Results presented in this section for MF $285 \mathrm{~S}$ tractor (1500 rpm engine speed), and the mouldboard plough (3 bottoms, $1.22 \mathrm{~m}$ working width), were obtained at the selected four forward speed $(1.8,2.23,3.88$ and 4.68 $\mathrm{km} / \mathrm{h}$ ), three inflation pressures of rear wheel $(50,100$ and $150 \mathrm{kPa})$, two soil moisture contents (14.67\% and $24.18 \%$ dry basis) and ploughing depth (from 10 to $20 \mathrm{~cm}$ )

\section{1-rolling resistance}

The obtained data for rolling resistance are presented Fig. (3). It is clear that the rolling resistance increased with increasing the forward speed it increased by an range 39\% with, increasing the forward speed from 2.23$4.68 \mathrm{~km} / \mathrm{h}$ at $100 \mathrm{kPa}$ inflation pressure, and $14.67 \%\left(\mathrm{M}_{\mathrm{cbd}}\right)$ soil moisture content. Also, It can be noticed that the rolling resistance at $100 \mathrm{kPa}$ inflation pressure of rear wheel was less than the rolling resistance at 50 $\mathrm{kPa}$ and $150 \mathrm{kPa}$ inflation pressure for all the forward speed (from 1.8 to $4.68 \mathrm{~km} / \mathrm{h}$ ) and soil moisture content of $14.67 \%$ and $24.18 \%$ dry basis. 
This may be due to the area of the tire in contact with the soil which was suitable at $100 \mathrm{kPa}$ but it was bigger at $50 \mathrm{kPa}$, and smaller at $150 \mathrm{kPa}$ which led to wheel splaying, and wheel diving, respectively consequently, both of wheel splaying and wheel diving increased the rolling resistance. For example, (from 1.8 to $4.68 \mathrm{~km} / \mathrm{h}$ ) and $14.67 \%$ soil $\left(\mathrm{M}_{\mathrm{cbd}}\right)$, the rolling resistance at $50 \mathrm{kPa}$ and $150 \mathrm{kPa}$ increased by an average $51 \%$ and $53 \%$ comparing with rolling at $100 \mathrm{kPa}$ inflation pressure, respectively.

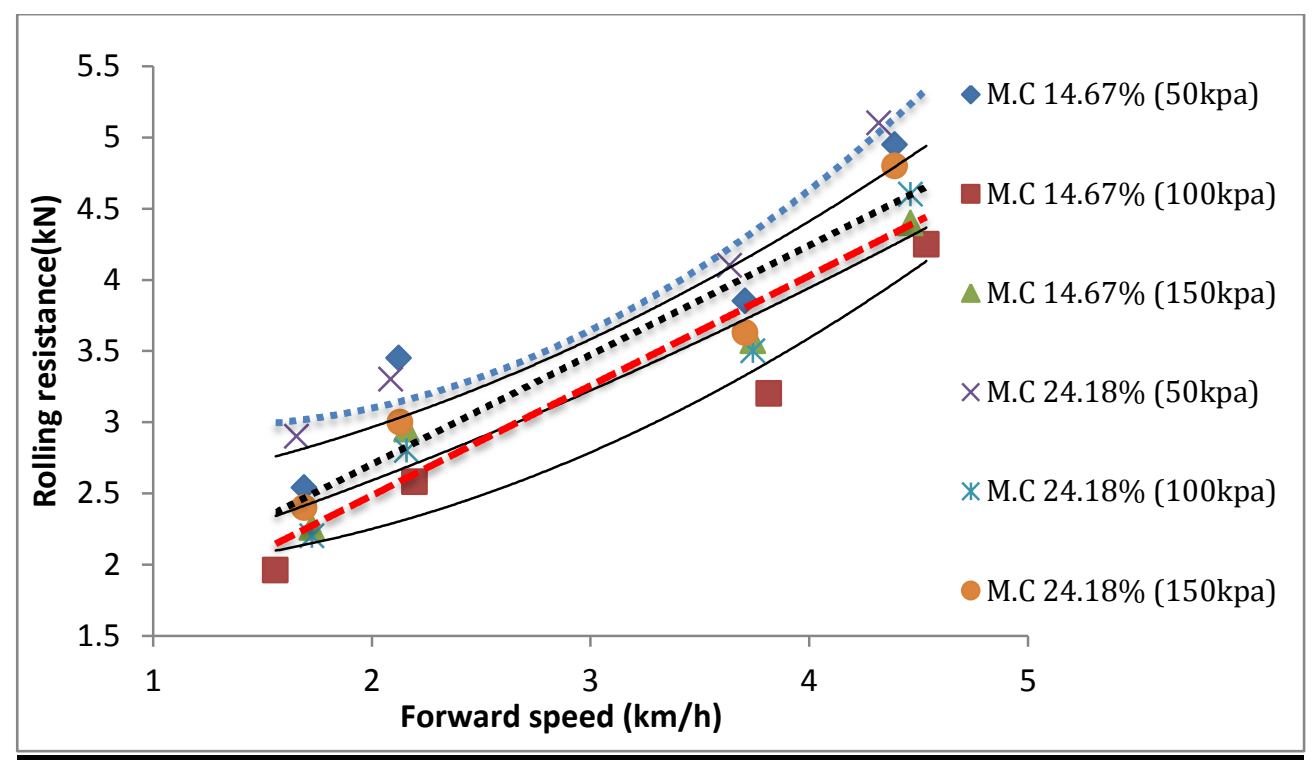

Fig(3). Rolling resistance as a function of forward speed at different inflation pressure of rear wheel and $14.67 \%, 24.18 \% \mathrm{M}_{\mathrm{cbd}}$

\section{2- Drawbar Pull and wheel slip}

The effect of forward speed and inflation pressure of rear wheels on the drawbar pull and wheel slip at $14.67 \%$ and $24.18 \% \mathrm{M}_{\mathrm{cbd}}$, are illustrated in Figs.(4) and (5), respectively. It is obvious that both of the drawbar and wheel slip increased with the increase of the forward speed. The drawbar pull and the wheel slip at $100 \mathrm{kPa}$ inflation pressure and $14.67 \%$ soil $\mathrm{M}_{\mathrm{cdb}}$ increased by an average (18.18\% and $34.95 \%)$ with increasing the forward speed from 1.73 to $4.39 \mathrm{~km} / \mathrm{h}$. It is also clear that both of the rolling resistance and wheel slip at $100 \mathrm{kPa}$ inflation pressure are less than their values at $50 \mathrm{kPa}$ and $150 \mathrm{kPa}$ for all the selected forward speed 
and soil moisture content. This also could be due to wheel splaying and wheel diving, respectively. At $4.68 \mathrm{~km} / \mathrm{h}$ and $14.67 \%$ soil $\mathrm{M}_{\mathrm{cdb}}$, the drawbar pull and wheel slip at $50 \mathrm{kPa}$ and $150 \mathrm{kPad}$ inflation pressure were increased during ploughing by an average $(16 \%, 37 \%)$ and $(17 \%$, $35 \%$ ), comparing with their values at $100 \mathrm{kPa}$, respectively

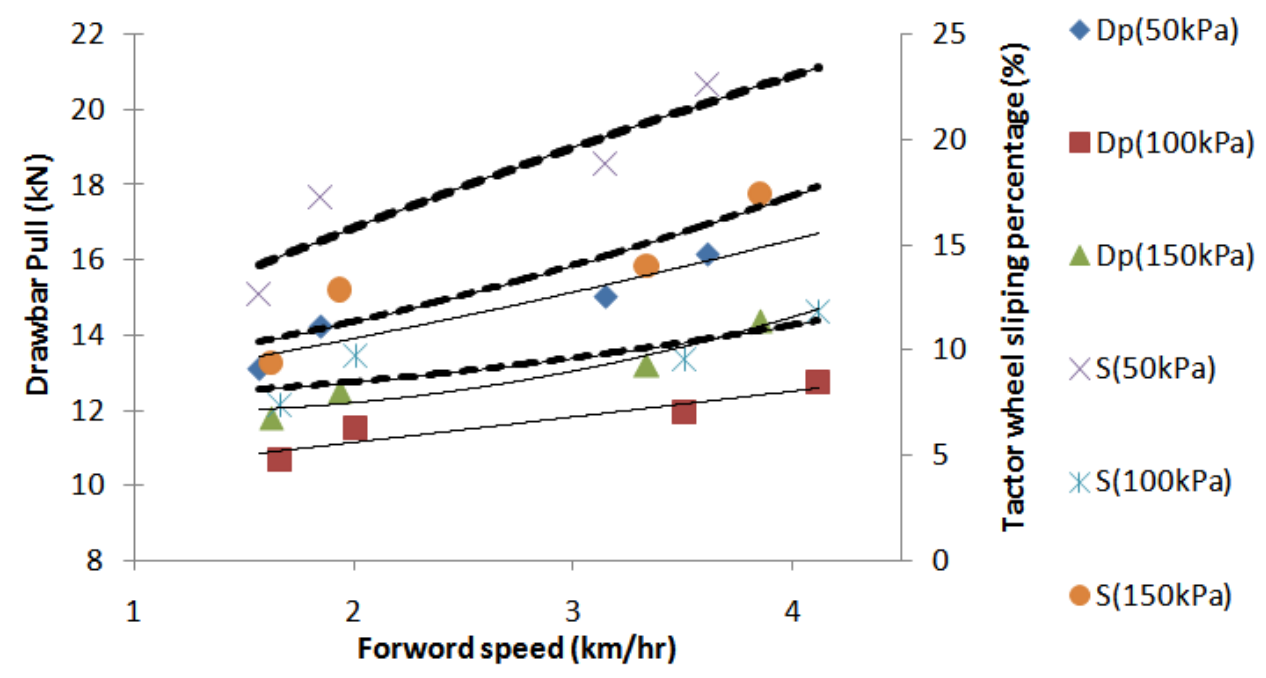

Fig. (4) Effect of travelling speed and different inflation pressure on drawbar pull and wheel slip during ploughing at $14.67 \%$ soil $\mathrm{M}_{\mathrm{cbd}}$

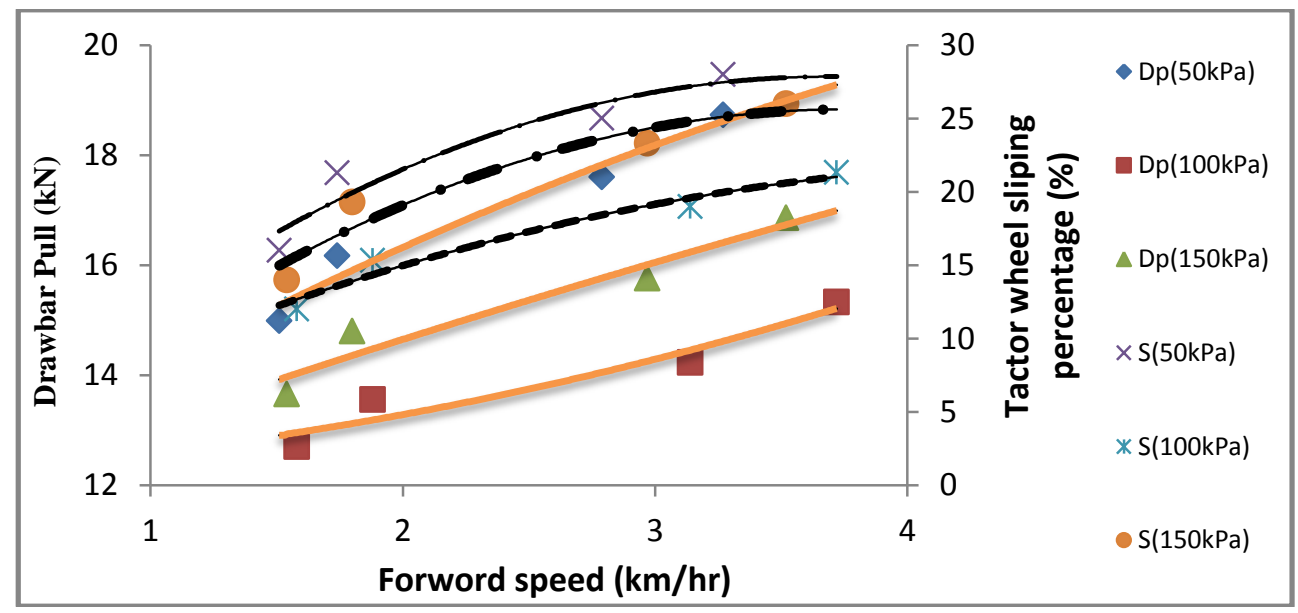

Fig. (5) Effect of travelling speed and different inflation pressure on drawbar pull and wheel slip during ploughing at 24.18 soil $\mathrm{M}_{\mathrm{cbd}}$ 


\section{3-Tractive efficiency}

Fig.(6) show the effect of the forward speed and inflation pressure of rear wheel at $14.67 \%$ and $24.18 \%$ soil $\mathrm{M}_{\mathrm{cdb}}$ on the tractive efficiency .It is clear that for all the selected forward speed ,the tractive efficiency decreased by increasing the forward speed. The tractive efficiency decreased by average $13 \%$ with increasing the forward speed from 1.8 to $4.68 \mathrm{~km} / \mathrm{h}$ and $14.67 \%$ soil $\mathrm{M}_{\mathrm{cdb}}$. This may be due to the losses in output power that could be refered to slip or pull losses. That is very clear in Figs. (7) and (8) where the tractive efficiency decreased with increasing the percent of wheel slip. At $100 \mathrm{kPa}$ inflation pressure and $14.67 \%$ soil $\mathrm{M}_{\mathrm{cdb}}$, the tractive efficiency decreased with an average $15 \%$ with increasing the percent of wheel slip from $7.33 \%$ to $11.39 \%$. Fig. (6) also shows that the increase of tractive efficiency by an average $7.3 \%$ with increasing the inflation pressure from $50 \mathrm{kPa}$ to $100 \mathrm{kPa} 4.2 \mathrm{~km} / \mathrm{h}$ forward speed and $14.67 \%$ soil $\mathrm{M}_{\mathrm{cdb}}$. This may be due to the use of the correct tire inflation pressure and size. However, increasing the inflation pressure from $100 \mathrm{kPa}$ to $150 \mathrm{kPa}$ at the same conditions, decreased the tractive efficiency by an average $4.4 \%$ as a result of tire diving.

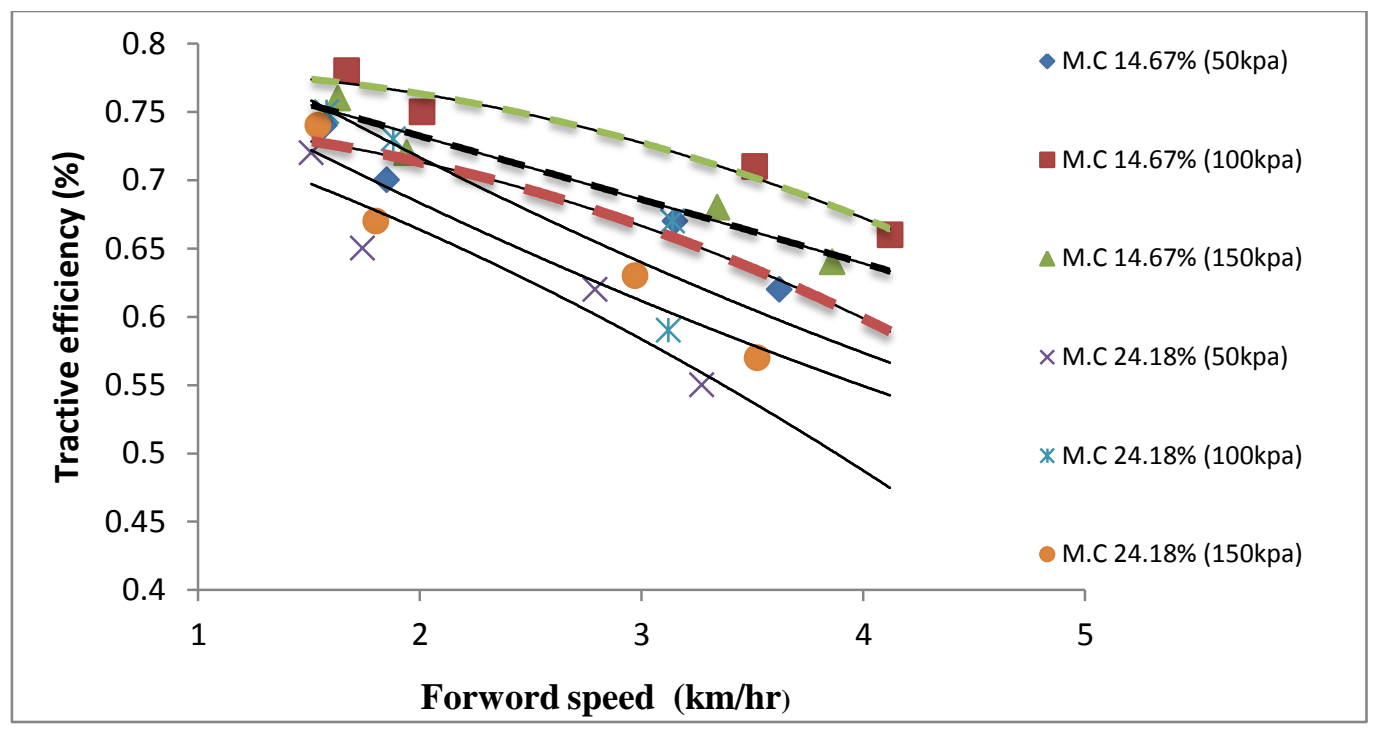

Fig. (6): Effect of forward speed and inflation pressure on tractive efficiency during ploughing at 14.67 and $24.18 \%$ soil Mcbd. 


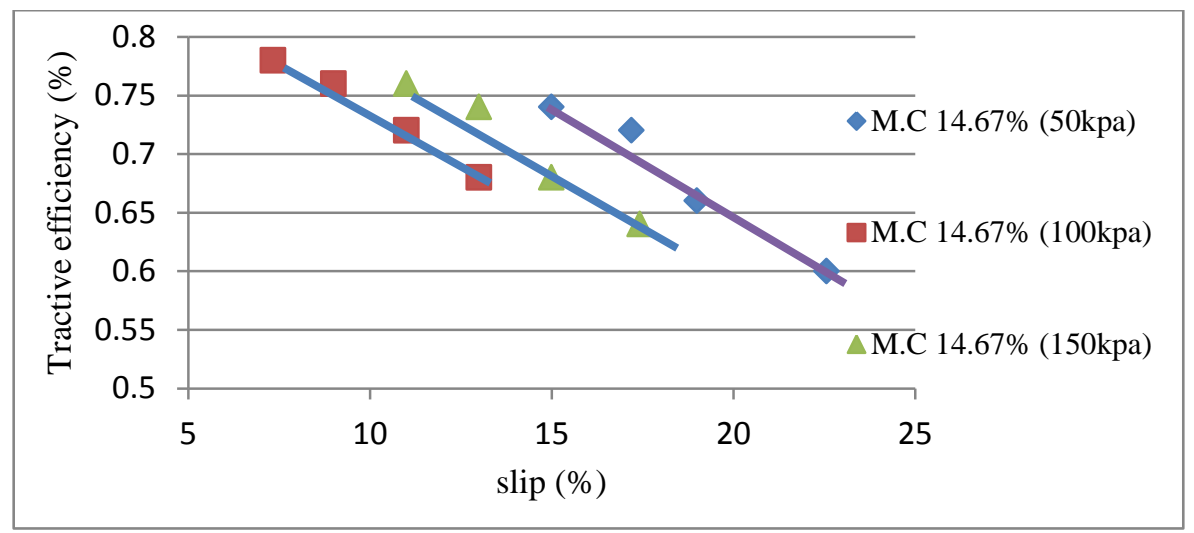

Fig. (7): Relationship between tractive efficiency and wheel slip during ploughing at different tire pressure and $14.67 \%$ soil $\mathrm{M}_{\mathrm{cbd}}$.

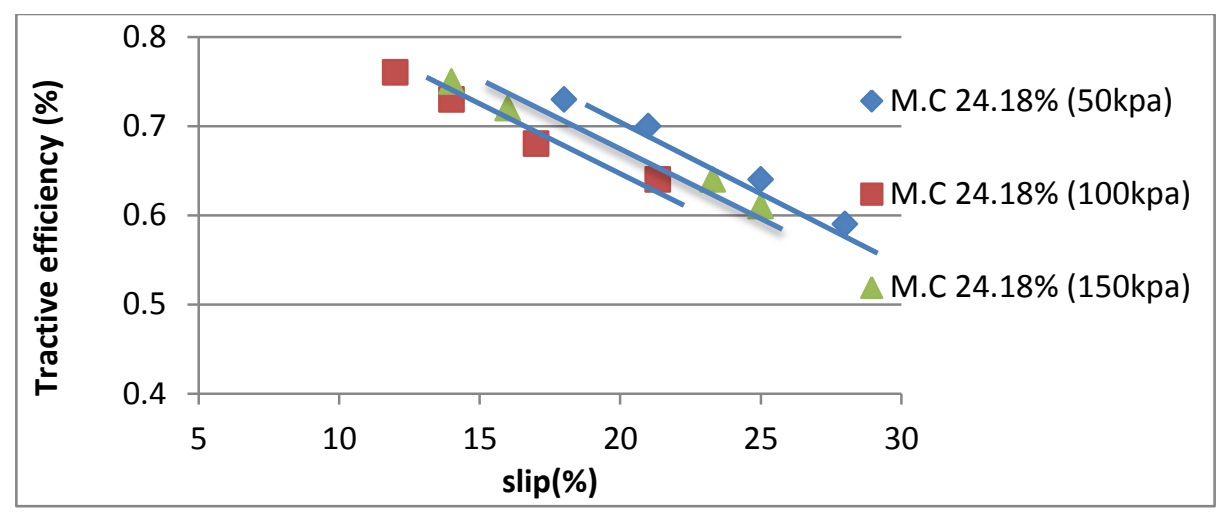

Fig. (8): Relationship between tractive efficiency and wheel slip during ploughing at different tire pressure and $24.18 \%$ soil $\mathrm{M}_{\mathrm{cbd}}$

\section{4-Effective field capacity and field efficiency.}

Figs.(9) and (10) shows the effect of the forward speed and inflation pressure of the rear wheels on the effective field capacity and field efficiency at $14.67 \%$ and $24.18 \%$ soil $\mathrm{M}_{\mathrm{cbd}}$. In general, the effective field capacity increased with the increase of forward speed but was slight decrease of the field efficiency with increasing the forward speed which may be due to the increase in theoretical field capacity. At $100 \mathrm{kPa}$ inflation pressure and $14.67 \%$ soil $\mathrm{M}_{\mathrm{cdb}}$.the effective field capacity increased by an average 57\% with increasing the forward speed from 1.8 to $4.68 \mathrm{~km} / \mathrm{h}$ while there was slight decrease (about 9\%) of the field efficiency. The highest value of the effective field capacity was $1.56 \mathrm{fed} / \mathrm{h}$ at $4.39 \mathrm{~km} / \mathrm{h}$ and $100 \mathrm{kPa}$ inflation pressure, $14.67 \%$ soil $\mathrm{M}_{\mathrm{cdb}}$. 


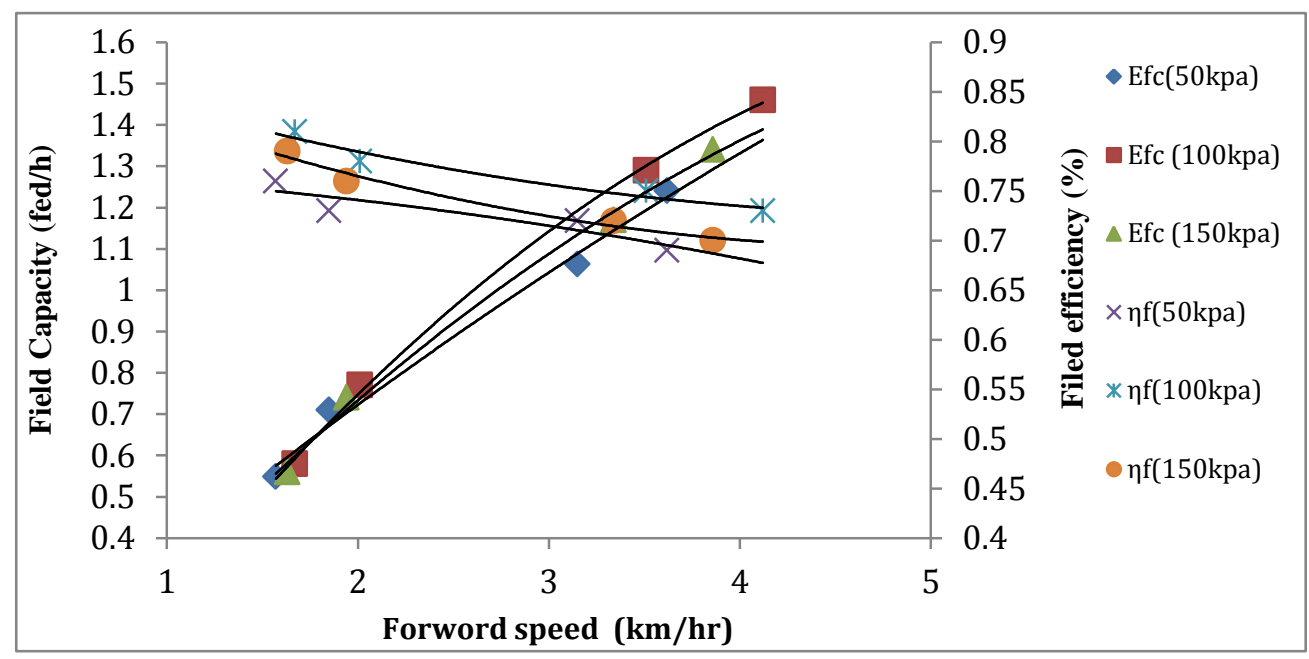

Fig. (9): Effect of forward speed and inflation pressure on the effective field capacity and field efficiency at $14.67 \%$ soil $\mathrm{M}_{\mathrm{cdb}}$.

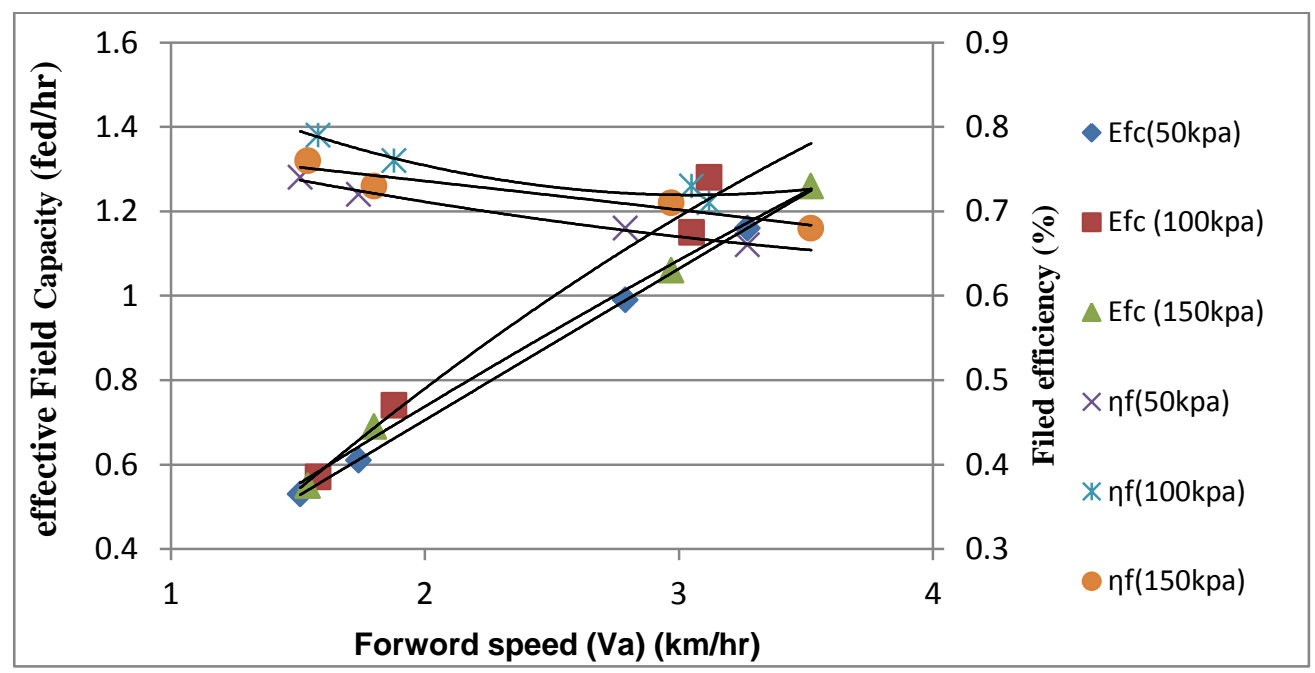

Fig. (10): Effect of forward speed and inflation pressure on the effective field capacity and field efficiency at $24.18 \%$ soil $\mathrm{M}_{\mathrm{cdb}}$.

\section{5-Fuel consumption and drawbar specific fuel consumption.}

Figs. (11) and (12) shows the effect of the forward speed and inflation pressure on the fuel consumption and drawbar specific fuel consumption at $14.67 \%$ and $24.18 \%$ soil $\mathrm{M}_{\mathrm{cdb}}$. It can be noticed that the fuel consumption was increased while the drawbar specific fuel consumption 
was decreased with increasing the forward speed. The fuel consumption increasing by an average $34 \%$, while the drawbar specific fuel consumption decreased by an average $39 \%$ with increasing the forward speed from 1.8 to $4.68 \mathrm{~km} / \mathrm{h}$, at $14.67 \%$ soil $\mathrm{M}_{\mathrm{cdb}}$. The highest value of the fuel consumption was $9.2 \mathrm{l} / \mathrm{h}$ at $4.39 \mathrm{~km} / \mathrm{h}$ travelling speed, in the mean time the drawbar specific fuel consumption was $0.6 \mathrm{l} / \mathrm{kW} . \mathrm{h}$, $14.67 \%$ soil $\mathrm{M}_{\mathrm{cdb}}$

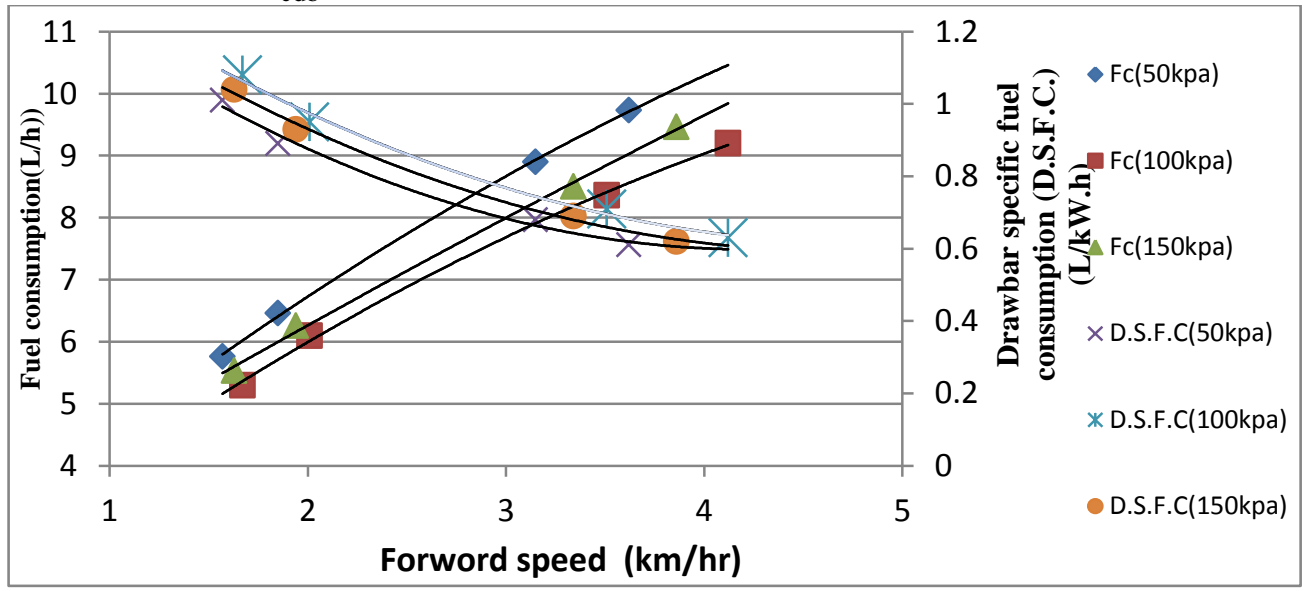

Fig. (11): Effect of forward speed and inflation pressure on the fuel consumption and drawbar specific fuel consumption at $14.67 \%$ soil $\mathrm{M}_{\mathrm{cdb}}$.

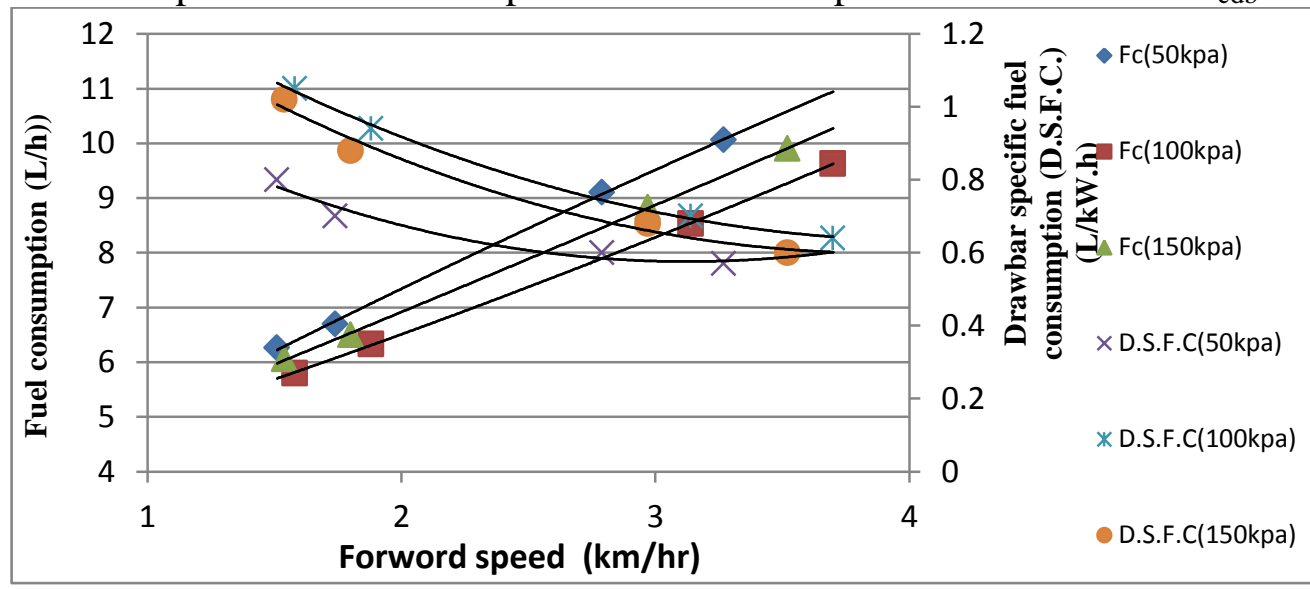

Fig. (12): Effect of forward speed and inflation pressure on the fuel consumption and drawbar specific fuel consumption at $24.18 \%$ soil $\mathrm{M}_{\mathrm{cdb}}$.

\section{5-Required engine power and specific energy.}

Figs. (13) and (14) shows the effect of travelling speed and the inflation pressure of rear tractor wheels on the required power $(\mathrm{kW})$ and the 
specific energy (kW.h/fed) at $14.67 \%$ and $24.18 \%$ soil Mcbd. It's obvious that by increasing the travelling speed, the required power was increased, while the specific energy was decreased the required power was increased by $58 \%$ and the specific energy was decreased by $29 \%$ when the travelling speed increased (from 1.73 to $4.39 \mathrm{~km} / \mathrm{h}$ ). At $4.39 \mathrm{~km} / \mathrm{h}$ travelling speed, $100 \mathrm{kPa}$ inflation pressure, and $14.67 \%$ soil $\mathrm{M}_{\mathrm{cdb}}$, the highest value of the required power was $39 \mathrm{~kW}$, while the specific energy was $19 \mathrm{~kW} . \mathrm{h} / \mathrm{fed}, 14.67 \%$ soil $\mathrm{M}_{\mathrm{cdb}}$.

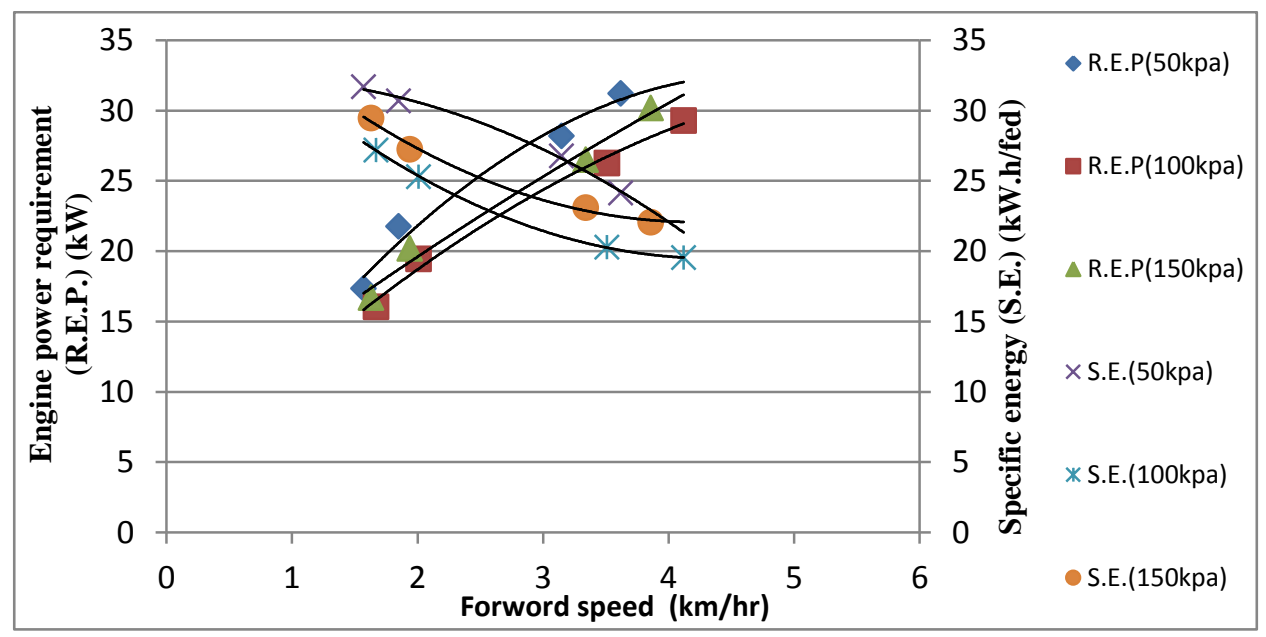

Fig. (13): effect of travelling speed and inflation pressure on power requirement and specific energy at $14.67 \%$ soil $\mathrm{M}_{\mathrm{cdb}}$

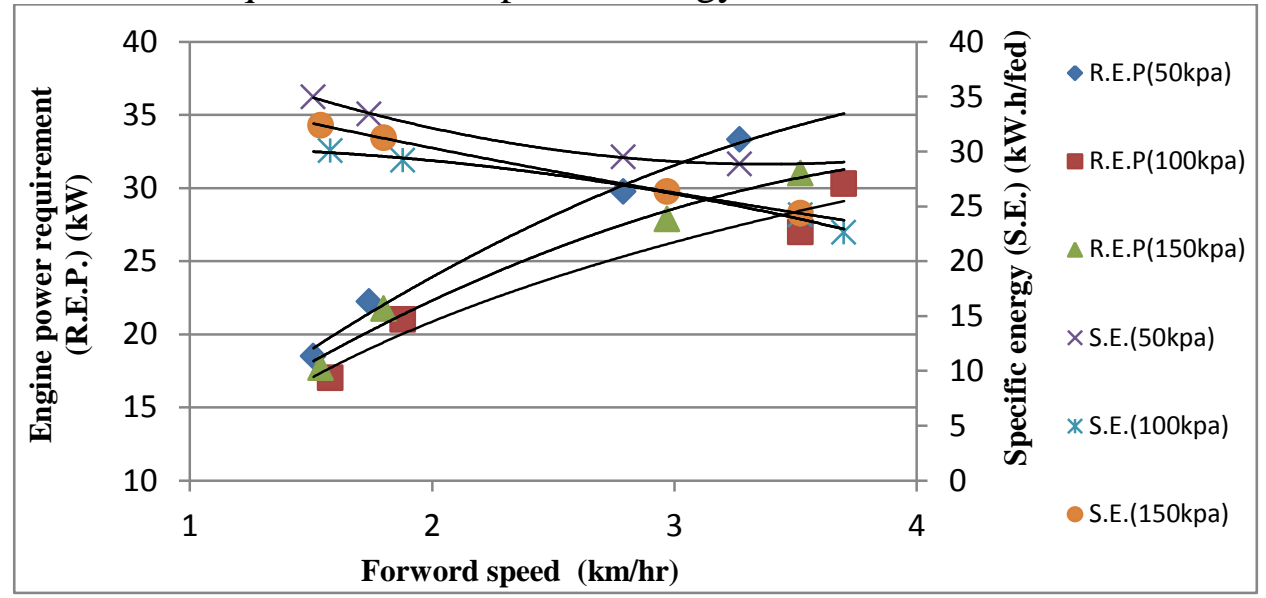

Fig. (14): effect of travelling speed and inflation pressure on power requirement and specific energy at $24.18 \%$ soil $\mathrm{M}_{\mathrm{cdb}}$ 


\section{CONCLUSION}

The results of the present study led to the following conclusions:

1 - The travelling speed and inflation pressure on the rear tractor wheels were the most important factors that affecting the drawbar pull and the specific energy.

2 - The minimum drawbar pull and the wheel slip was obtained at $100 \mathrm{kPa}$ inflation pressure and 14.6 soil $\mathrm{M}_{\mathrm{cdb}}$.

3 - Increasing rolling resistance and slippage with increasing forward speed.

4 - The higher value of tractive efficiency (79\%) was obtained at $100 \mathrm{kPa}$ inflation pressure and 14.6 soil $\mathrm{M}_{\mathrm{cdb}}$. at $1.8 \mathrm{~km} / \mathrm{h}$ travelling speed.

5 - The highest value of the required power was $27.76 \mathrm{~kW}$ at $4.39 \mathrm{~km} / \mathrm{h}$ travelling speed, in the mean time the specific energy was $16.10 \mathrm{~kW} . \mathrm{h} / \mathrm{fed}$ for tyre pressure $(100 \mathrm{kPa})$ at soil moisture $(14.67 \%)$

\section{REFERENCES}

Abdel-Wahab, M.K., 1994. Minimum Tillage by a Simple Combination. Misr.J. Ag.Eng.,11(3):711-724

Abraham et.al.,2014.Increase in tractor drawbar pull using special wheels .Agronomy Research 12(1),7-16

Al,Ani Rifaat Namnq,and Abdul fatah 1995. Study of the influence of high forward speed and different depths for plough on some independent indications for with Antar tractor 71 in Abu-Grab Reiom Magazine of Agricultural Sciences 26(3)216-265.

Al-Suhaibani S.A. and A.E.Ghaly, 2009. Effect of Ploughing Depth of Tillage and Forward Speed on the Performance of a Medium size Chiesel Plow Operating in a Sandy Soil. American Journal of Agricultural and Biological Sciences 5(3): 247-255.

Bahnas O. T., H. A. El-Gendy, and M.A. El-Attar 2004. Effect of some Strip-Till Methods on Maize Grain Yield. Misr.J. Ag.Eng.,conference 141-156.

Black C.A., D.D. Evans, J. L. White , L.E. Ensminger, and F.E. clark, 1965. Method of Soil Analysis (part1), Physical and Mineralogical Properties, Including Statistics of Measurements and Sampling, American Society of Agronomy, Inc., Publisher Madison, Wisconsin, USA . PP:357-377 and 552-557. 
Barger, E.L., J.B. Liljedahl, W.M. Carleton and E.G. Mckibben, 1963. Tractor and their Power Units. 2nd ed., John Wiley \& Sons, New york, USA.

Bukhari S.B, and J.M. Baloch, 1982. Fuel Consumption of Tillage Implements, AMA, Vol.(13):20-22. Ag.Eng.,conference :141-156.

Embaby A. T., 1985. A Comparison of the Different Mechanization Systems for Cereal crop Production M. Sc. Thesis, Agric. Eng. Dep., Fac. of Ag., Cairo Univ

Gee-Clough,D. 1980. Selection of tira siz for agricultural Vehicles.Engng.Res.25(3): 261-278.

Hunt D., 1983. Farm Power and Machinery Management. Iowa state University press, Ames, Iowa, USA

Jebur H.A., M. M. Mostafa; E. A. El-Sahhar; M. A. El-Attar.,and M. A. Elnono 2013. Performance Evaluation Of Farm Tractor Using Variable Weights On Rear Wheels During Ploughing And Sowing Operations. Misr J. Ag. Eng., 30 (3): 645 - 66

Jebur H.A., 2010. Studying of Effect and Interference Soil Moisture and Plowing Depth on the Drag Force Resistance and Total Economical Costs for Mechenary Unit. Al-taqani journal,23(2):81-91.

Khader K.A.A., 2008. Effect of Some Primary Tillage Implement on Soil Pulverization and Specific Energy, Misr.J. Ag .Eng., 25(3): 731-745.

Khan M.A., and I. Ari, 1980. Traction Potential of Pneumatic Tyre for Tractor. A. M. A., Spring 77-82

Lyasko M.I., 2010. How to Calculate the Effect of Soil Conditions onTractive Performance. Journal of Terramechanics, April , p 1-23.

Lyne,P.W.L and E.C.But. 1989. Real-time optimization of tractive efficiency .Trans .of the ASAE 32(2):431-43

Sarhan A.M.M , H.S. Al-Katary, and M.N. El-Awady, 2010. A Study on Agricultural Tractors Steering Mechanism. The 17th. Annual Conference of the Misr J. Ag .Eng., 27(4):981-1002.

Sharma D. N., and S.Mukesh, 2010. "Design of Agricultural Tractor (principles and problems). Published by Shri Sunil Kumar Jain for 
Jain Brothers (New Delhi) 16/873, East Park Road, New Delhi -110 005. First Edition, P.No: 199 - 213.

Sümer S.K., and Alaettin Sabanci, 2004. Effects of Different Tire Configurations on Tractor Performance. Turk. J. Agric. For 29(2005) 461-468. (C) TÜBITAK

Tomkins F.D., and L.R. Wilhelm. 1982. Energy Inputs to Selected Tillage Implements. Proc. of the Beltwide Cotton Prod. Res. Conf. jan. 3-7, Las Vegas, Nevada: 151-152.

Younis S.M., R.E. EL-Said, F.B. Ahmed., and M.E. Islam, 2010.

Development a Local System for Measuring Tractors Performance. Misr.J. Ag. Eng., 27(1):34-53.

\section{الملخص العربى}

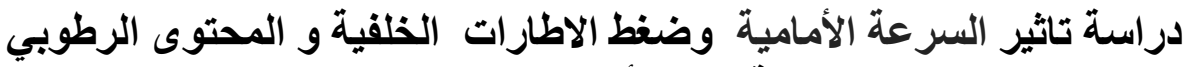
للتربة على الأداء الحقلي للجرار الأبل

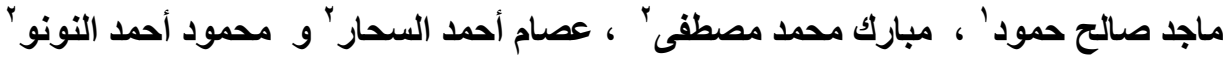

الأهداف من الدراسة هو استخدام جرار ماسي فوركسن للتحقيق في مستويات مختلفة, تأثير

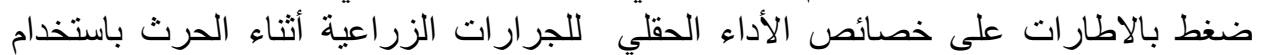

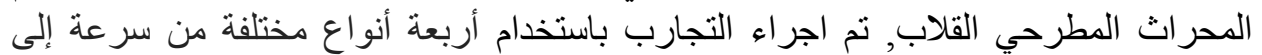

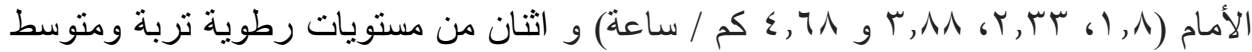

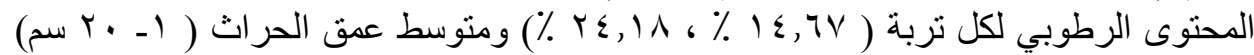

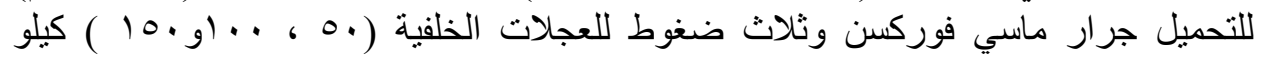

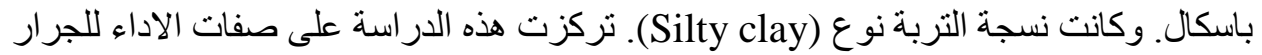

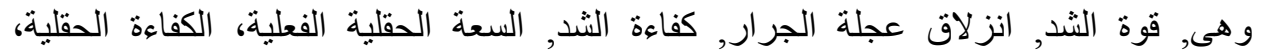

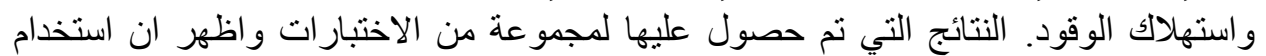

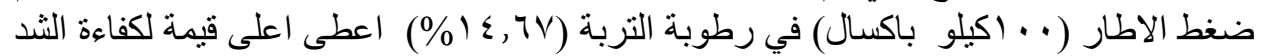

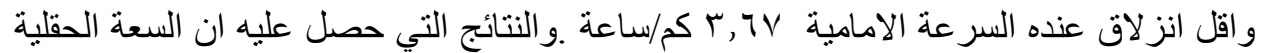

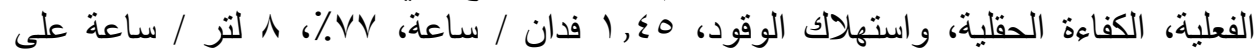

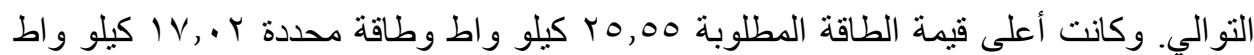

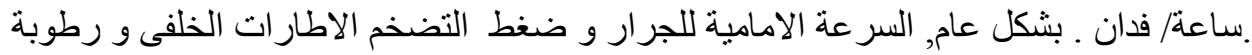

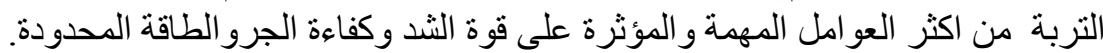

ا طالب دراسات عليا- كلية الزراعة - جامعة عين شمس .

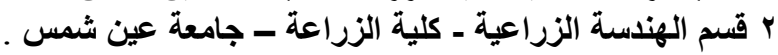

